ISSN 0103-5150

Fisioter. Mov., Curitiba, v. 28, n. 2, p. 231-240, Apr./June 2015

Licenciado sob uma Licença Creative Commons DOI: http://dx.doi.org.10.1590/0103-5150.028.002.A003

\title{
Mobility, balance and muscle performance according to self-efficacy for falls in the elderly
}

\author{
Mobilidade, equilíbrio e desempenho muscular \\ segundo a autoeficácia para quedas em idosas
}

\section{Carolina Raíssa Bento Pereira da Silva, Ricardo Oliveira Guerra, Aline Medeiros Cavalcanti da Fonsêca, Andréa de Carvalho Gomes, Álvaro Campos Cavalcanti Maciel*}

Universidade Federal do Rio Grande do Norte (UFRN), Natal, RN, Brazil

\begin{abstract}
Introduction: Changes in mobility, postural balance and muscle strength in the aging process may cause a fall in the elderly by changing or not perceived self-efficacy in preventing falls, the goal is to compare mobility, body balance and muscle performance according to self-efficacy for falls in community-dwelling elderly women. Materials and methods: A comparative study of cross-section, with 63 communitydwelling elderly. We evaluated sociodemographic data, cognition (Mini-Mental State Examination), efficacy for falls (International Efficacy Scale for Falls, Brazil), mobility (Timed Up and Go Test), body balance by Berg Balance Scale, Balance Master System: Modified Clinical Test of Sensory Interaction on Balance (mCTSIB), Tandem walk (TW) Sit to Stand (STS) and muscular performance by isokinetic dynamometry.
\end{abstract}

* CRBPS: MSc, e-mail: raissabentops@gmail.com ROG: PhD, e-mail: roguerra@ufrnet.br AMCF: MSc, e-mail: alinemeca@gmail.com ACG: MSc, e-mail: physiotherapist_andrea@yahoo.com.br ACCM: PhD, e-mail: alvarohuab@ig.com.br 
Using the cutoff point at or above 23 points, two groups, G1 with low perceived efficacy in preventing falls $(n=36)$ and $G 2$ with high perceived efficacy in preventing falls $(n=27)$ were allocated. Student's $t$ test was performed for comparison between groups, with $p$ value of 0.05 . Results: Comparing the elderly women regarding the efficacy of falls, significant differences were observed in the variables Timed Up and Go Test $(p=0.04)$, speed of oscillation test mCTSIB $(p=0.01)$ and the isokinetic dynamometry knee extension movement, peak torque $(p=0.04)$ and power $(p=0.03)$. Conclusion: Comparing communitydwelling elderly women with low and high efficacy for falls, significant differences were in variables related to mobility, body balance and muscle function.

Keywords: Aging. Postural balance. Muscle strength.

\section{Resumo}

Introdução: Alterações na mobilidade, equilíbrio postural e força muscular no processo de envelhecimento podem ocasionar queda em idosos, alterando ou não a autoeficácia percebida em evitar quedas. Objetivo: Comparar mobilidade, equilíbrio corporal e desempenho muscular segundo a autoeficácia para quedas em idosas comunitárias. Materiais e métodos: Estudo comparativo de corte transversal com 63 idosas comunitárias. Foram avaliados dados sociodemográficos; cognição (Mini Exame do Estado Mental); eficácia para quedas (Escala de Eficácia de Quedas Internacional, Brasil); mobilidade (Timed Up and Go Test); equilíbrio corporal pela Escala de Equilíbrio de Berg, pelo Balance Master System: Modified Clinical Test of Sensory Interaction on Balance (mCTSIB), pelo Tandem walk (TW) e pelo Sit to Stand (STS); e desempenho muscular pela dinamometria isocinética. Por meio do ponto de corte igual ou acima de 23 pontos, foram alocados dois grupos: G1, com baixa eficácia percebida em evitar queda $(n=36)$ e G2, com alta eficácia percebida em evitar queda $(n=27)$. Foi realizado o teste $\mathrm{t}$ de Student para comparação entre grupos, com $p$ valor de 0,05. Resultados: Comparando as idosas em relação à eficácia para quedas, encontrou-se diferenças significativas nas variáveis Timed Up and Go Test $(p=0,04)$, na velocidade de oscilação do teste mCTSIB $(p=0,01)$ e nas variáveis da dinamometria isocinética no movimento de extensão do joelho, pico de torque $(p=0,04)$ e potência $(p=0,03)$. Conclusão: Comparando idosas de comunidades com baixa e alta eficácia para quedas, observaram-se diferenças nas variáveis relacionadas à mobilidade, equilíbrio corporal e função muscular.

Palavras-chave: Envelhecimento. Equilíbrio Postural. Força muscular.

\section{Introduction}

Falls in the elderly represent today an important theme within the rehabilitation process, since it can have consequences such as physical injuries, functional losses and psychological implications, such as the fear of falling $(1,2)$. Some researchers have referred to the fear of falling as a feeling of uneasiness with loss in confidence or balance disorders, depression, anxiety and reduction of social contacts (3). Another frequently used term, self-efficacy is defined as the abilities perceived by the individual or selfconfidence in dealing with a particular situation (4).

According to Bandura (5), self-efficacy component is a self-regulatory mechanism by which people exercise control over motivation, thinking styles and emotional life. It is an individual's coping strategy for containing threats he considers fearful. In this sense, perceived self-efficacy in preventing falls is the perception that the subject has to avoid falls, in the face of a non-dangerous everyday practices. In contrast, low self-efficacy or loss of confidence in avoiding falls is defined as the fear of falling, or inefficiency in dealing with falls in the elderly that makes an individual fearful (5).

The said term seems to be related to physical function and performance in everyday activities, suggesting that the sense of present and urgent danger resonates effects in the body that make it suitable for defensive reaction to become active $(3,4)$.

It has been observed that elderly with lowefficacy for falls have slow gait, greater number of 
co-morbidities and depressive symptoms. These aspects are linked to reduced mobility, balance abnormalities with or without falls and muscle weakness, generating a negative impact on the physical and mental condition of this population $(6,7,8)$.

Lopes et al. (9) found a significant moderate correlation between mobility, dynamic balance and risk of falls, emphasizing that the restriction of movement results in loss of physical conditioning, muscle atrophy, balance deficit and dependence on Activities of Daily Living (ADLs). From the above link between the variables related to the physical aspects, it is necessary to emphasize the importance of self-efficacy perceived preventing falls in the psychological context, as the belief in the ability to perform a function allows for the accomplishment of the same.

Considering that, the level of confidence that the individual has in their abilities is a strong motivator and regulator of their behavior. For example, when I believe that I can climb a ladder I realize the task, this conception can interfere in aspects such as mobility, balance and muscle strength, as the balance between the physical and mental components preserves health in biopsychosocial context.

In view of the above, despite reduced muscle strength, balance disorders and mobility being described as potential risk factors for falls in the elderly, the possible relationship of these variables with selfefficacy for falls in the elderly have not been clearly established until now. Thus, the aim of this study is to compare mobility, body balance and muscle performance according to self-efficacy for falls in elderly resident in community.

\section{Materials and methods}

This is a comparative cross-sectional study, with population of women aged from 65 to 80 years residing in the community and who were attending two groups of elderly in the city of Natal, with data collection period between March and September 2012.

The sample included 63 elderly women and was selected by voluntary demand among those who met the following inclusion criteria: being female, living in the community independently and age equal to or over 65 years. All signed the Informed Consent Form, considering the ethical aspects based on the Declaration of Helsinki and the National Health Council Resolution 196/96. The project was approved by the Research Ethics Committee (Comitê de Ética em Pesquisa - CEP) at Onofre Lopes Teaching Hospital (Hospital Universitário Onofre Lopes - HUOL), under the protocol number 637/11.

Exclusion criteria considered were: presented neurological alterations and/or musculoskeletal such as brain strokes sequelae, Parkinson's disease, amputations in the upper and/or lower limbs, fractures of the lower limbs or spine that prevented the completion of the evaluation and cognitive status incompatible with schooling assessed by the MiniMental State Examination (MMSE) (10).

All participants were evaluated through a protocol containing identification and socio-demographic data (age, body weight, height, marital status, and years of schooling); regular practice physical activity; history of falls in the last six months; along with the Mini Mental State Examination (MMSE); International Falls Efficacy Scale - Among Elderly Brazilians (FES-I-BRAZIL) (4); Timed Up and Go Test (TUGT) (11); Berg Balance Scale (BBS) (12); Smart Balance Master ${ }^{\mathrm{TM}}$ tests (13) and the isokinetic test with Biodex System $3^{\mathrm{TM}}$ dynamometer (14).

MMSE is composed of 30 items, with subtests that assess spatiotemporal orientation, immediate memory, recall, attention and language. It adopted the cut-off points suggested by Brucki et al. (15).

The FES-I-BRASIL assigns values to 16 daily activities living (DAL) according to the degree of concern in the elderly fall to carry them out. As for the score that can be verified by applying the ratio, it varies from one to four per item, reaching a total score of 16 to 64 points, the adopted cut-off point is equal to or more than 23 points to characterize low efficacy perceived in avoiding fall. It should be noted that as the value of the total score increases the degree of concern about falling also rises (4). Individuals who were less effective in avoiding perceived fall were allocated to the G1 ( $n=36), G 2$ group is composed of the elderly with high perceived efficacy in preventing fall $(\mathrm{n}=27)$.

The TUGT analyzes the time spent by the individual as part of an initial position sitting with the back supported in a chair, without the aid of the upper limbs, walk a linear path of three meters up to a predetermined point marked on the floor, rotates $180^{\circ}$, returns and sits down again, supporting the back in the same chair. The patient is instructed to perform the test using their usual shoes, they do not talk during the implementation and do it at a normal 
speed, in a safe manner. Higher values of time represent higher risks of falls (11).

The Berg Balance Scale (BBS) evaluates the performance of functional balance, analyzing it quantitatively based on 14 items common to everyday life, and the tasks are performed in this order: seated position to a standing position; remain standing without support; remain seated without support; standing position to a sitting position; transfer from one chair to another; remain in a standing position with eyes closed; remain standing with feet together; on foot, reach forward with the elbows extended; on foot, picking up an object from the floor; turn to look back; rotate 360 degrees; positioning the feet alternately on a stair; remain on foot with a foot ahead; and stay on one foot (12).

The maximum score that can be achieved is $\mathbf{5 6}$ points where each item has an ordinal scale of five alternatives ranging from 0 to 4 points (14). For its application, just a digital stopwatch, a tape measure, a platform of 20 inches tall, a chair of 42 inches tall with arm rests and back and another chair of 42 inches tall with support for back and without support for arms. Score equal or below 45 points is considered suggestive of balance disorders, being a risk factor of falls (12).

In relation to the Balance Master three tests were selected: 1. modified Clinical Test of Sensory Interaction on Balance (mCTSIB) that analyzes the static postural balance quantifying the speed of oscillation in the individual standing on the platform in different conditions: eyes open on a firm surface; eyes closed on a firm surface; eyes open unstable surface (foam); closed eyes on an unstable surface (foam).

To analyze the balance on unstable surface, we used a foam block integrated with the Balance Master system which is $50 \mathrm{~cm}$ in length and breadth, $20 \mathrm{~cm}$ in height and a density of $0.5 \mathrm{~kg} / \mathrm{m}^{3}$. For the closed-eye condition, a mask for blindfolding that came with the device was used. 2-0 Tandem Walk (TW), which quantifies the dynamic postural balance by the characteristics of walking in tandem by the participant (heel of one foot leaned on the toes of the other foot), where the parameters measured are: width of step, speed and oscillation of the trunk in reference to the center of gravity.

The third and final test, the Sit to Stand (STS) also evaluated dynamic postural balance quantifying the participant's ability to rise from a stable surface, positioned on the wooden platform of the system. This task includes changing the centre of gravity forward in the initial position and on the support base (feet), followed by trunk extension in the upright position with maintenances of the same (13).

The parameters measured in the Sit to Stand (STS) were weight transfer time, force exerted when climbing, speed oscillation during the rise phase and symmetry of the left and right body hemisphere. For implementation of the three tests, all subjects performed each condition for 30 seconds (three attempts of 10 seconds), where the device recorded the oscillation of the center of gravity during each run.

Regarding isokinetic dynamometry, three series of five concentric isokinetic contractions a rate of $60^{\circ} / \mathrm{s}$ were performed to evaluate the muscular performance of the flexor group and member of the right knee extensor, with two minutes rest between sets. The said speed is adopted, because it is the most suitable and safe for isokinetic in the elderly and due to the fact that the smaller the angular velocity, the greater the torque $(16,17)$. Through the concentric contractions we obtained on record: agonist/ antagonist ratio, peak torque, peak torque to body weight and average power during the movement of the aforementioned joint.

The collected data were analyzed descriptively by means of the statistical package SPSS version 17.0. Kolmogorov-Smirnov test was used to check for normality, while Student's t-test was used to compare the means of mobility, balance and muscle strength values between groups of low and high efficacy for falls. At all stages of the statistical analysis, the level of significance $\mathrm{p}<0.05$ and a confidence interval (CI) of $95 \%$ were considered.

\section{Results}

Sixty three women were evaluated, with a mean age of $70.6( \pm 4.5)$ years and prevalence of low self-efficacy for falls of $57.1 \%$. Other sample characteristics are presented in Table 1.

According to the International Falls Efficacy Scale Among Elderly Brazilians (FES-I-BRASIL), the sample was divided into two groups, where 36 volunteers were assigned to the low efficacy for falls group and another 27 volunteers in high efficiency for falls group. On the analysis between the groups, there was significant difference only in the variable of Timed Up and Go Test (TUGT) $(\mathrm{p}=0.04)$, as shown in Table 2 . 
Table 3 shows data on the Balance Master System $^{\mathrm{TM}}$ tests. Difference was found only for the variable speed oscillation on firm surface with eyes opened $(p=0.01)$.
For the isokinetic dynamometry variables, there were no significant differences in knee extension movement with respect to the peak torque variable $(\mathrm{p}=0.04)$ and power $(\mathrm{p}=0.03)$, as shown in Table 4 .

Table 1 - Characteristics of the sample of 63 Community-dwelling elderly women of Natal, RN, 2012

\begin{tabular}{|c|c|c|c|c|c|}
\hline & & Mean & $\pm s d$ & N & $\%$ \\
\hline Age (years) & & 70.6 & 4.5 & & \\
\hline Year of education & & 9.7 & 4.9 & & \\
\hline Body mass (kg) & & 65.1 & 12.0 & & \\
\hline Height (cm) & & 153.8 & 6.1 & & \\
\hline $\begin{array}{l}\text { Mini Mental State } \\
\text { Examination (MMSE) (points) }\end{array}$ & & 27.1 & 2.4 & & \\
\hline EEB (points) & & 53.7 & 2.0 & & \\
\hline $\begin{array}{l}\text { Timed Up and Go Test } \\
\text { (seconds) }\end{array}$ & & 8.9 & 1.6 & & \\
\hline FES-I-BRASIL (points) & & 25.9 & 7.9 & & \\
\hline \multirow[t]{4}{*}{ Marital status } & Single & & & 13 & 20.6 \\
\hline & Married & & & 15 & 23.8 \\
\hline & Divorced & & & 9 & 14.3 \\
\hline & Widowed & & & 26 & 41.3 \\
\hline \multirow{2}{*}{ * Physical activity } & No & & & 22 & 34.9 \\
\hline & Yes & & & 41 & 65.1 \\
\hline \multirow{2}{*}{ Self-efficacy } & High & & & 27 & 42.8 \\
\hline & Low & & & 36 & 57.1 \\
\hline \multirow{2}{*}{ Fall } & Yes & & & 52 & 82.5 \\
\hline & No & & & 11 & 17.5 \\
\hline
\end{tabular}

Note: *Physical activity self-reported.

Table 2 - Mean and standard deviation ( \pm sd) of the independent variables according to self-efficacy of falls in the Community-dwelling elderly women of Natal, RN, 2012

\begin{tabular}{|c|c|c|c|c|c|}
\hline \multirow{3}{*}{ Variables } & \multicolumn{4}{|c|}{ FES-I-BRASIL } & \multirow[b]{3}{*}{$\mathrm{p}$} \\
\hline & \multicolumn{2}{|c|}{ 0-22 points } & \multicolumn{2}{|c|}{ Above 23 points } & \\
\hline & Mean & $\pm s d$ & Mean & $\pm s d$ & \\
\hline Age (years) & 70.2 & 4.5 & 70.9 & 4.5 & 0.54 \\
\hline Year of education & 9.8 & 5.7 & 9.7 & 4.3 & 0.95 \\
\hline Body mass (kg) & 62.8 & 10.1 & 66.9 & 13.1 & 0.18 \\
\hline
\end{tabular}


Table 2 - Mean and standard deviation ( \pm sd) of the independent variables according to self-efficacy of falls in the Community-dwelling elderly women of Natal, RN, 2012

\begin{tabular}{|c|c|c|c|c|c|}
\hline \multirow{3}{*}{ Variables } & \multicolumn{4}{|c|}{ FES-I-BRASIL } & \multirow[b]{3}{*}{$\mathrm{p}$} \\
\hline & \multicolumn{2}{|c|}{ 0-22 points } & \multicolumn{2}{|c|}{ Above 23 points } & \\
\hline & Mean & $\pm s d$ & Mean & $\pm s d$ & \\
\hline Height (cm) & 154.3 & 7.1 & 153.4 & 5.3 & 0.58 \\
\hline $\begin{array}{l}\text { Mini Mental State } \\
\text { Examination (MMSE) (points) }\end{array}$ & 27.7 & 1.6 & 26.7 & 2.8 & 0.10 \\
\hline EEB (points) & 54.0 & 1.7 & 53.5 & 2.1 & 0.34 \\
\hline $\begin{array}{l}\text { Timed Up and Go Test } \\
\text { (seconds) }\end{array}$ & 8.5 & 1.2 & 9.3 & 1.7 & 0.04 \\
\hline
\end{tabular}

Table 3 - Mean and standard deviation ( \pm sd) of the variables in the balance master system on self-efficacy function in falls in the Community-dwelling elderly women of Natal, RN, 2012

\begin{tabular}{|c|c|c|c|c|c|}
\hline \multirow{3}{*}{ Variables } & \multicolumn{4}{|c|}{ FES-I-BRASIL } & \multirow[b]{3}{*}{$\mathrm{p}$} \\
\hline & \multicolumn{2}{|c|}{ 0-22 points } & \multicolumn{2}{|c|}{ Above 23 points } & \\
\hline & Mean & $\pm s d$ & Mean & $\pm s d$ & \\
\hline $\begin{array}{l}\text { Firm surface oscillation } \\
\text { speed with eyes open } \\
\text { (mCTSIB) }(\% / s)\end{array}$ & 0.15 & 0.09 & 0.22 & 0.12 & 0.01 \\
\hline $\begin{array}{l}\text { Firm surface oscillation } \\
\text { speed with closed eyes } \\
\text { (mCTSIB) }(\% / \mathrm{s})\end{array}$ & 0.19 & 0.11 & 0.21 & 0.10 & 0.53 \\
\hline $\begin{array}{l}\text { Unstable surface oscillation } \\
\text { speed with eyes open } \\
\text { (mCTSIB) ( } \% \text { s) }\end{array}$ & 0.87 & 0.51 & 0.94 & 0.49 & 0.50 \\
\hline $\begin{array}{l}\text { Unstable surface oscillation } \\
\text { speed with eyes closed } \\
\text { (mCTSIB) }(\% / s)\end{array}$ & 1.49 & 0.5 & 1.48 & 0.4 & 0.94 \\
\hline Speed (TW)(cm/s) & 18.4 & 7.6 & 17.9 & 8.3 & 0.79 \\
\hline Step width $(\mathrm{TW})(\mathrm{cm})$ & 8.6 & 2.9 & 9.5 & 3.8 & 0.30 \\
\hline Final oscillation $(\mathrm{TW})(\% / \mathrm{s})$ & 6.1 & 1.2 & 6.5 & 1.5 & 0.27 \\
\hline Weight transfer (STS) (s) & 0.40 & 0.19 & 0.47 & 0.22 & 0.23 \\
\hline $\begin{array}{l}\text { Speed of oscillation COG } \\
\text { (STS) }(\% / s)\end{array}$ & 3.4 & 1.0 & 3.6 & 1.1 & 0.26 \\
\hline Weight symmetry (STS) (\%) & -6.2 & 11.2 & -3.4 & 9.0 & 0.27 \\
\hline $\begin{array}{l}\text { Rise index (STS) (\% body } \\
\text { weight) }\end{array}$ & 11.6 & 3.8 & 11.5 & 5.3 & 0.98 \\
\hline
\end{tabular}


Table 4 - Mean and standard deviation ( $\pm \mathrm{sd}$ ) of the variables of the isokinetic dynamometry according to the self-efficacy of falls Community-dwelling elderly women of Natal, RN, 2012

\begin{tabular}{|c|c|c|c|c|c|}
\hline \multirow{3}{*}{ Variables } & \multicolumn{4}{|c|}{ FES-I-BRASIL } & \multirow[b]{3}{*}{$\mathrm{p}$} \\
\hline & \multicolumn{2}{|c|}{$0-22$ points } & \multicolumn{2}{|c|}{ Above 23 points } & \\
\hline & Mean & $\pm s d$ & Mean & $\pm s d$ & \\
\hline $\begin{array}{l}\text { Relation agonist antagonist } \\
\text { (extension) (\%) }\end{array}$ & 54.3 & 10.7 & 56.0 & 12.2 & 0.55 \\
\hline Peak torque (extension) (Nm) & 70.9 & 13.7 & 62.5 & 17.6 & 0.04 \\
\hline $\begin{array}{l}\text { Peak torque to body weight } \\
\text { (extension) (\%) }\end{array}$ & 104.3 & 45.3 & 96.6 & 30.0 & 0.41 \\
\hline Power (extension) (watts) & 39.5 & 7.6 & 34.4 & 10.5 & 0.03 \\
\hline Peak torque (flexion) (Nm) & 37.8 & 8.4 & 33.8 & 9.1 & 0.08 \\
\hline $\begin{array}{l}\text { Peak torque to body weight } \\
\text { (flexion) (\%) }\end{array}$ & 55.5 & 23.9 & 52.6 & 15.1 & 0.56 \\
\hline Power (flexion) (watts) & 23.4 & 6.9 & 20.2 & 8.1 & 0.10 \\
\hline
\end{tabular}

\section{Discussion}

In gerontological assessment, the focus is to make a comprehensive analysis of the individual. Features such as capturing of sociodemographic data and application of mini mental state examination help in investigation facilitating identification of a probable disorder in cognition. Being a criterion for inclusion in the study, the average MEEM observed is compatible with the preserved cognition, and being an indispensable evaluation tool as Scheffer et al. (7) observed cognitive complaints and low financial resources in the elderly who had fear of falling.

From the point of view of rehabilitation, it is crucial to understand various relations between falls and the measures of muscle strength, postural control and mobility. In this sense, BBS that is widely used in research with the elderly has shown that postural balance remained within the normal patterns of age (18).

The average FES-I scale found in the study (25.9 points) puts the elderly at a level of sporadic possibility of falling, as established by Camargos (4). Self-efficacy for fall assessed by FES-I was also used in Sweden and was presented as a highly reliable questionnaire to assess fear of falling among the elderly in the Community (19). In a literature review, epidemiological studies showed 21-61\% among the elderly who have experienced fear of falling independent of having been dropped; indicating that this may contribute to both the functional decline and to reduced quality of life (20).

In relation to the average score of TUGT ( $8.9 \mathrm{~s}$ ), it was observed that in general the elderly women are classified in the group of subjects without problems of balance, since the cut-off point of this parameter is 20 seconds (21). However, a significant difference was found between the older of the two groups $(p=0.04)$ with the worst results in the group above 23 points in the FES-I. This result corroborates the findings of Aveiro et al. (22) that generalize TUGT as a test that assesses strength and power of lower limbs with regard to mobility and therefore is the best predictor for defining an individual as a faller or non faller. In contrast, although the difference between the groups, are found to be within normal parameters since none of the elderly subjects approached the 20 seconds in the testing time. It is believed that the results found here seems to point to the fact that a more compromised future for those who attained more time in the test.

In contrast, although the difference between the groups, parameters observed are within the normal range since none of the elderly subjects approached the 20 seconds in the testing time. The results presented here seem to point to a compromised future for those that attained higher time in the testing.

Still depicting the use of TUGT as a strategy for the assessment of mobility, Kumar et al. (23) observed significant association between this variable and mobility. 
Ben Achour Lebib et al. (24) in a systematic review suggest the standardization of this test, because age, gender, and co-morbidities affect the time of completion of the same. Kwan et al. (21) stated that TUGT has more accurate results in more compromised patients when compared to healthy subjects and non-fallers.

With regard to the assessment of postural balance, the Balance Master System ${ }^{\mathrm{TM}}$ provides data on postural balance and vestibular system, playing an important role in the early assessment of gait problems and risk of falls in the elderly, in addition to allowing rehabilitation of the impaired balance. In this sense, Binda et al. (25) compared elderly with high efficacy with the low efficacy for falls, identified in the elderly community-dwelling with fear of falling, some limitations in the ability to balance while the muscle strength did not differ between the 2 groups. A significant difference in mCTSIB test to Balance Master System ${ }^{\mathrm{TM}}$ is with respect to oscillation speed on the firm surface with eyes open, and as similarly discussed in this study by Mirka and Black (26) affirming that the elderly need to increase oscillation, in order to compensate for their lack of ability to maintain postural balance seeking greater sensory interaction.

Regarding muscle performance, in particular the peak torque and capacity of the knee extensors, where significant differences were found, it is known that the power of the muscles of the lower limbs is an important factor, together with force, influences physical performance of the elderly (27). Keskin et al. (28) showed that the muscular performance of knee extensors and flexors is not a significant factor for fall or risk of falling in elderly women, especially for those with preserved functionality. Foldavari et al. (29) showed that the peak knee extension power is an independent predictor of functional capacity reported by community-dwelling women, suggesting that the decline in muscle function is by age and gender. However, Deschenes et al. (30) reported that, in general, loss of muscle strength leads to greater difficulties in balance and increased risk of falls.

Despite the consistency of the results in this study, some limitations need to be considered mainly because of that it was a convenience sample, which limits its external validity preventing these results to be generalized. However, it is possible to target a therapeutic practice by increasing functionality encompassing these three variables with the opportunity to preserve self-efficacy for falls.

\section{Conclusion}

The results indicated the presence of low efficacy for falls in community-dwelling elderly, showing the effectiveness International Falls Efficacy Scale - Among Elderly Brazilians (FES-I-BRASIL) as appropriate strategy for the assessment of how the individual feels able to perform a task without the occurrence of falls. In this regard, it is suggested that comparing low and high efficacy groups for fall, there is statistically significant differences as regards mobility, static balance and muscle strength. However, new research is needed for deeper understanding of the results presented in this work.

\section{References}

1. Rezende AAB, Silva IL, Cardoso FB, Beresford H. Medo do idoso em sofrer quedas recorrentes: a marcha como fator determinante da independência funcional. Acta Fisiatr. 2010;17(3):117-21.

2. Beck AP, Antes DL, Meurer ST, Benedetti TRB, Lopes MA. Fatores associados às quedas entre idosos praticantes de atividades físicas. Texto Contexto Enferm. 2011;20(2):280-6.

3. Costa EM, Pepersack T, Godin I, Bantelle M, Petit B, Lêveque A. Fear of falling and associated activity restriction in older people: results of a cross-sectional study conducted in a Belgian town. Arch Public Health. 2012;70(1):1-8.

4. Camargos FFO. Adaptação transcultural e avaliação das propriedades psicométricas da falls efficacy scale - international: um instrumento para avaliar medo de cair em idosos [dissertação]. Belo Horizonte: Universidade Federal de Minas Gerais; 2007.

5. Bandura A. The evolution of social cognitive theory. In: Smith KG, Hitt MA, editor. Great minds in management. Oxford; New York: Oxford University Press; 2005. p. 9-35.

6. Perracini MR, Teixeira LF, Ramos JLA, Pires RS, Najas MS. Fall-related factors among less and more active older outpatients. Rev Bras Fisioter. 2012; 16(2):166-72. 
7. Scheffer AC, Shuurmans MJ, Van Dijk N, Van Der Hoof T, De Rooij SE. Fear of falling: measurement strategy, prevalence, risk factors and consequences among older persons. Age Ageing. 2008;37(1):19-24.

8. Dias RC, Freire MTF, Santos EGS, Vieira RA, Dias JMD, Perracini MR. Características associadas à restrição de atividades por medo de cair em idosos comunitários. Rev Bras Fisioter. 2011;15(5):406-13.

9. Lopes KT, Costa DF, Santos LF, Castro DP, Bastone AC. Prevalência do medo de cair em uma população de idosos da comunidade e sua correlação com mobilidade, equilíbrio dinâmico, risco e histórico de quedas. Rev Bras Fisioter. 2009;13(3):223-9.

10. Folstein MF, Folstein SE, Mchugh PR. "Mini-mental state": a practical method for grading the cognitive state of patients for the clinician. 1975;12(3):189-98.

11. Podsiadlo D, Richardson S. The Timed "Up \& Go": a test of basic functional mobility for frail elderly persons. J Am Geriatr Soc. 1991;39(2):142-8.

12. Miyamoto ST, Lombardi Junior I, Berg KO, Ramos LR, Natour J. Brazilian version of the Berg balance scale. Braz J Med Biol Res. 2004;37(9):1411-21.

13. NeuroCom International, Inc. Balance master operators manual. Version 7.0. Clackamas; 1999.

14. Biodex Medical Systems, Inc. System 3 Pro. Appicartion/operation manual. [cited 2013, Jan 20th] Available from: http://www.biodex.com/sites/default/ files/835000man_06159.pdf

15. Brucki SMD, Nitrini R, Caramelli P, Bertolucci PHF, Okamoto IH. Sugestões para o uso do mini-exame do estado mental no Brasil. Arq. Neuro-Psiquiatr. 2003;61(3B):777-81.

16. Pereira LSM, Dias RC, Dias JMD, Gomes GC, Sitta MI. Fisioterapia. In: Freitas EV, Py L, Neri AL, Cançado FAX, Gorzoni ML, Rocha SM. Tratado de Geriatria e Gerontologia. Rio de Janeiro: Guanabara Koogan; 2006. p. 1198-209.

17. Aquino MA, Leme LEG, Amatuzzi MM, Greve JMD, Terreri ASAP, Andrusaitis FR, et al. Isokinetic assessment of knee flexor/extensor muscular strength in elderly women. Rev Hosp Clin Fac Med. 2002; 57(4):131-4.
18. Halvarsson A, Franzén E, Ståhle A. Assessing the relative and absolute reliability of the Falls Efficacy Scale-International questionnaire in elderly individuals with increased fall risk and the questionnaire's convergent validity in elderly women with osteoporosis. Osteoporos Int. 2013;24(6):1853-8

19. Gagnon N, Flint AJ. Fear of falling in the elderly. Geriatr Aging. 2003;6(7):15-7.

20. Gunter KB, White KN, Hayes WC, Snow CM. Functional mobility discriminates nonfallers from onetime and frequent fallers. J Gerontol A Biol Sci Med. 2000;55(11):M672-6.

21. Kwan MM, Lin SI, Chen CH, Close JC, Lord SR. Sensorimotor function, balance abilities and pain influence Timed Up and Go performance in older communityliving people. Aging Clin Exp Res. 2011;23(3):196-201.

22. Aveiro M, Driusso P, Barham EJ, Pavarini SCI, Oishi J. Mobilidade e risco de quedas de população idosa da comunidade de São Carlos. Ciênc Saúde Coletiva. 2012;17(9):2481-8.

23. Kumar S, Vendhan GV, Awasthi S, Tiwari M, Sharma VP. Relationship between fear of falling, balance impairment and functional mobility in community dwelling elderly. IJPMR. 2008;19(2):48-52.

24. Ben Achour Lebib S, Missaoui B, Miri I, Ben Salah FZ, Dziri C. Role of the Neurocom Balance Master in assessment of gait problems and risk of falling in elderly people. Ann Readapt Med Phys. 2006;49(5):210-7.

25. Binda SM, Culham EG, Brouwer B. Balance, muscle strength, and fear of falling in older adults. Exp Aging Res. 2003;29(2):205-19.

26. Mirka A, Black FO. Clinical application of dynamic posturography for evaluating sensory integration and vestibular disfunction. Neurol Clin. 1990;8(2):351-9.

27. Bean JF, Kiely DK, Herman S, Leveille SG, Mizer K, Frontera WR, et al. The relationship between leg power and physical performance in mobility-limited older people. J Am Geriatr Soc. 2002;50(3):461-7.

28. Keskin D, Borman P, Ersöz M, Kurtaran A, Bodur H, Akyüz M. The risk factors related to falling in elderly females. Geriatr Nurs. 2008;29(1):58-63. 
29. Foldavari M, Clark M, Laviolette LC, Bernstein MA, Kaliton D, Castaneda C, et al. Association of muscle power with functional status in community-dwelling elderly women. J Gerontol A Biol Sci Med Sci. 2000;55(4):M192-9.

30. Deschenes MR, Mccoy RW, Holdren NA, Eason MK. Gender influences neuromuscular adaptations to muscle unloading. Eur J Appl Physiol. 2009;105(6):889-97.

Received: 05/27/2013

Recebido: $27 / 05 / 2013$

Approved: $11 / 11 / 2014$

Aprovado: 11/11/2014 